\title{
Primary Mucosa-Associated Lymphoid Tissue (MALT) Lymphoma of Thyroid Gland Arising from Coexisting Hashimoto's Thyroiditis: A Case Report ${ }^{1}$
}

\author{
Sang Kwon Lee, M.D., Sun Young Kwon, M.D. ${ }^{,}$, Young Hwan Kim, M.D., Jin Soo Choi, M.D., \\ Chul Ho Sohn, M.D., Hee Jung Lee, M.D., Seongku Woo, M.D., Soo Ji Suh, M.D.
}

We report herein on a case of primary mucosa-associated lymphoid tissue (MALT) lymphoma of the thyroid gland in a 57-year-old woman with coexisting Hashimoto's thyroiditis, and we include its characteristic imaging, histopathologic and immunohistochemical findings.

\author{
Index words : Thyroid, neoplasms \\ Lymphoma \\ Thyroiditis
}

Even though the diagnostic accuracy of fine-needle aspiration cytology (FNAC) has increased to around 50$60 \%$ (1), chronic lymphocytic thyroiditis and small cell undifferentiated carcinoma (anaplastic carcinoma) are still being confused with thyroid lymphoma (2). No reports concerning the ultrasonographic (US) and computed tomographic (CT) features of primary mucosa-associated lymphoid tissue (MALT) lymphoma have yet been published in the Korean radiological literature.

We report herein on a case of MALT lymphoma of the thyroid gland in a patient with coexisting Hashimoto's thyroiditis, and the pathology results on FNAC mimicked lymphocytic or subacute thyroiditis. We also include MALT lymphoma's characteristic imaging findings.

\section{Case Report}

A 57-year-old woman visited our hospital for investigation of an incidentally found left anterior neck mass. On physical exam, an approximately $4 \times 5 \mathrm{~cm}$ sized, relatively fixed, nontender mass was found at her left anterior neck.

${ }^{1}$ Department of Radiology, Dongsan Medical Center, Keimyung University ${ }^{2}$ Department of Pathology, Dongsan Medical Center, Keimyung University Received January 23, 2006 ; Accepted April 17, 2006

Address reprint requests to : Sang Kwon Lee, M.D., Department of Radiology, Dongsan Medical Center, Keimyung University, College of Medicine, 194 Dongsan-dong, Jung-gu, Daegu 700-712, Korea.

Tel. 82-53-250-7735 Fax. 82-53-250-7766 E-mail: sklee@dsmc.or.kr
The results of the thyroid function test were as follow: the triiodothyronine level was $151.9 \mathrm{ng} / \mathrm{dL}$ (reference value: $80-200 \mathrm{ng} / \mathrm{dL}$ ), the thyroid stimulating hormone (TSH) level was $0.39 \mu \mathrm{IU} / \mathrm{mL}$ (reference value: below 5.0 $\mu \mathrm{IU} / \mathrm{mL}$ ), and the free $\mathrm{T} 4$ level was $1.74 \mathrm{ng} / \mathrm{dL}$ (reference value: $0.6-1.8 \mathrm{ng} / \mathrm{dL}$ ). A chest radiograph demonstrated mild cardiomegaly and right-sided deviation of the tracheal air column. US of the neck was performed for evaluating the palpable left anterior neck mass and this examination showed a diffusely enlarged inhomogeneously hypoechoic thyroid gland with increased intrathyroidal vascularity on the color Doppler images. About a $3.0 \times 3.0 \times 4.8 \mathrm{~cm}$ sized well circumscribed markedly hypoechoic solid mass was noted in the left thyroid lobe (Fig 1A and 1B). Echogenic linear strands on the gray-scale images (Fig. $1 \mathrm{~A}$ and $1 \mathrm{~B}$ ) and prominent color signals on the color Doppler images (Fig. 1C) were noted within the mass. The right thyroid lobe was not involved by the mass; it was inhomogeneously hypoechoic, which suggested Hashimoto's thyroiditis (Fig. 1D). Fine needle aspiration cytology (FNAC) was performed upon the mass. Histologically, there were small mature lymphocytes with occasional small to medium sized atypical lymphoid cells and also multinucleated giant cells; this was consistent with lymphocytic or subacute thyroiditis (Fig. 2). She was followed up at every two months for 10 months. During this period, the size 
of the thyroid mass didn't significantly change on palpation. The preoperative CT scan of the neck was performed at 10 months after the initial visit. Nonenhanced CT (NECT) demonstrated diffuse asymmetric enlargement of the thyroid gland (Fig. 4). The density of the thyroid gland was homogeneously lower than that of the muscles of the neck. A distinct mass was not identified on NECT. On contrast enhanced CT (CECT), the left thyroid lobe is nearly replaced by a large homogeneously enhancing solid mass measuring $3.6 \times 3.2 \times 5.0$ $\mathrm{cm}$ (Fig. 3). The density of the mass was slightly lower than that of the surrounding thyroid tissue. The thyroid tissue was hypodense and less enhanced compared with the normal thyroid gland of a comparable aged patient. No significantly enlarged lymph nodes were noted in the neck. Needle biopsy of the bone marrow demon- strated normocellular marrow. Radioimmunoassay (RIA) demonstrated markedly elevated thyroglobulin antibody $(1,556.40 \mathrm{IU} / \mathrm{mL}$ [reference value below 60 $\mathrm{U} / \mathrm{mL}]$ ), and microsomal antibodies (286.54 IU/mL [reference value; below $15.0 \mathrm{IU} / \mathrm{mL}]$ ); all these findings were consistent with Hashimoto's thyroiditis.

She underwent total thyroidectomy. The histologic (Fig. 4) and immunohistochemical (Fig. 5) findings were consistent with a primary MALT lymphoma in the left thyroid lobe arising from preexisting Hashimoto's thyroiditis. The right thyroid lobe also showed findings of Hashimoto's thyroiditis. The cervical lymph nodes and parathyroid glands were not involved by tumor. Her postoperative course was uneventful and there was no hypocalcemia or vocal cord paralysis.

She was given fractionated radiotherapy at a total dose
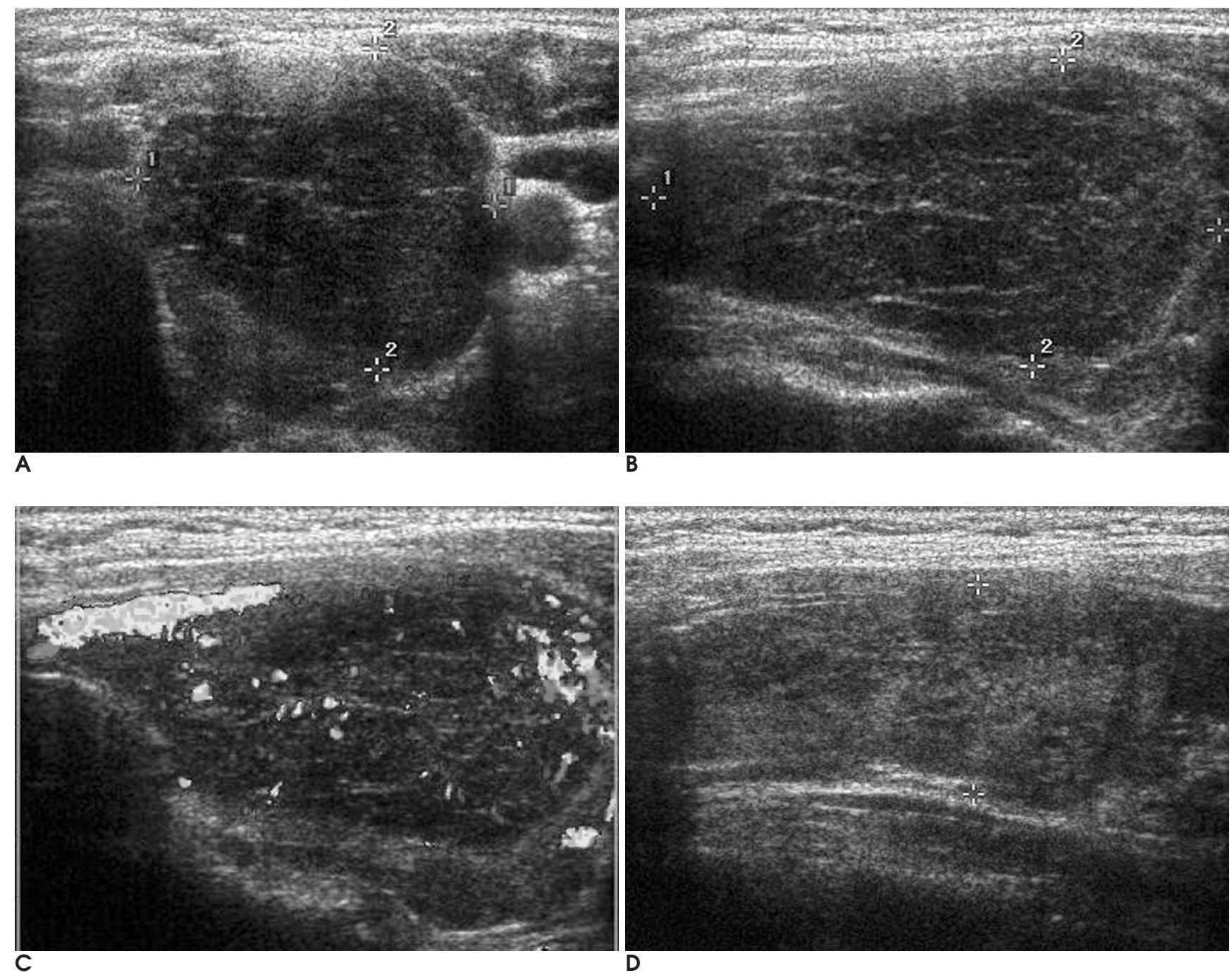

Fig. 1. Transverse $(\mathbf{A})$ and longitudinal $(\mathbf{B})$ gray-scale US demonstrate a large, well demarcated markedly hypoechoic mass with linear strands of increased echogenicity in the left thyroid lobe. Color Doppler image (C) shows increased color signals within the mass. The longitudinal image (D) demonstrates an enlarged inhomogeneously hypoechoic right thyroid lobe, which is consistent with Hashimoto's thyroiditis. 
of 45 Gy (180 cGy/fraction, 5 fractions/week for five weeks) directed at her neck and superior mediastinum, along with three courses of chemotherapy using cyclophosphamide, adriamycin, vincristine and prednisolone (CHOP) for treatment of the stage IE primary MLAT lymphoma of the thyroid gland. The follow-up CT scan after 32 months after her operation demonstrated no recurrent tumor or cervical lymphadenopathy.

\section{DISCUSSION}

Primary thyroid lymphomas account for 1.0\%- 3.5\% of all thyroid malignancies (3). Most thyroid lymphomas are of a B-cell origin with six different histologic subtypes, but there appears to be two distinct clinical and prognostic groupings of these rare tumors. The more indolent lymphomas are the subgroup of the mucosa-associated lymphoid tissue (MALT) lymphoma, and they comprise approximately $6 \%-27 \%$ of the thyroid lymphomas reported in the literature (4). The more common subtype that comprises up to $70 \%$ of all cases is the diffuse large B-cell lymphoma. This subtype appears to have the most aggressive clinical course with almost $60 \%$ of these tumors diagnosed as disseminated disease.
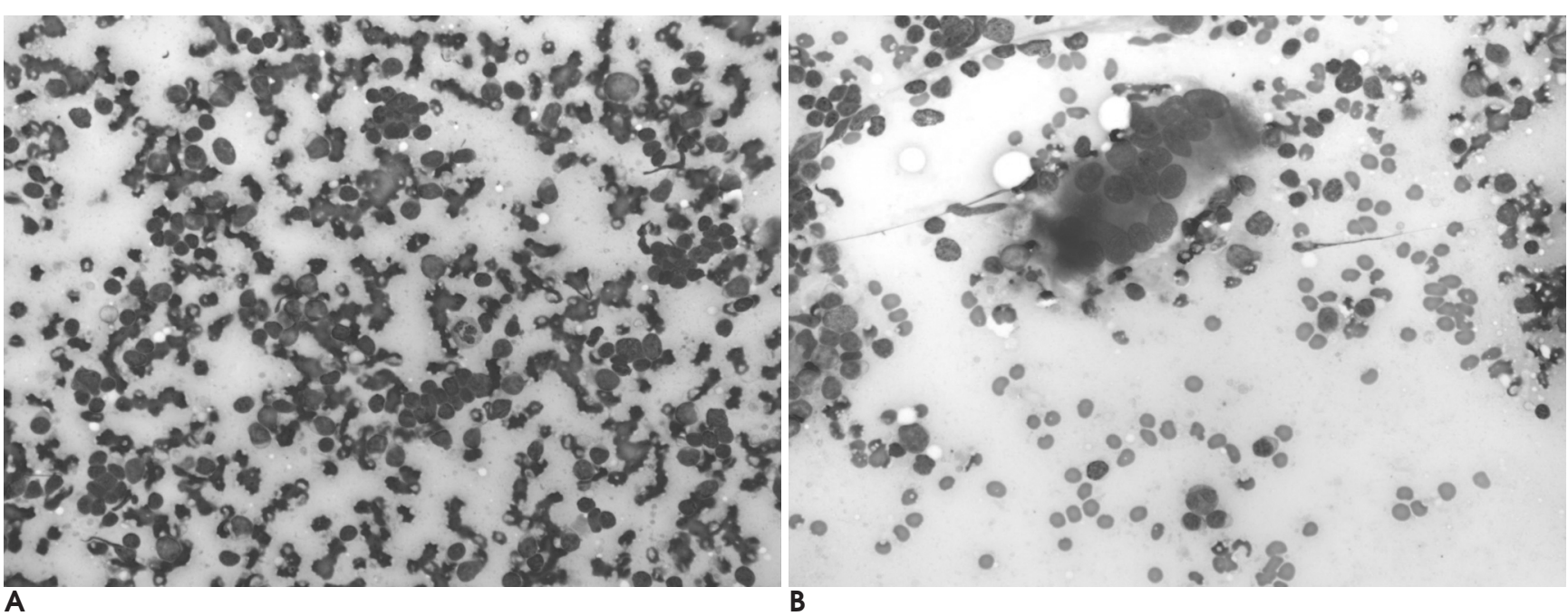

Fig. 2. Microscopic findings of the FNA smears demonstrate small to medium-sized atypical lymphoid cells admixed with small mature lymphocytes (A) (Diff-Quik stain, $\times 400)$, and also occasional multinucleated giant cells (B) (Diff-Quik stain, $\times 400)$.
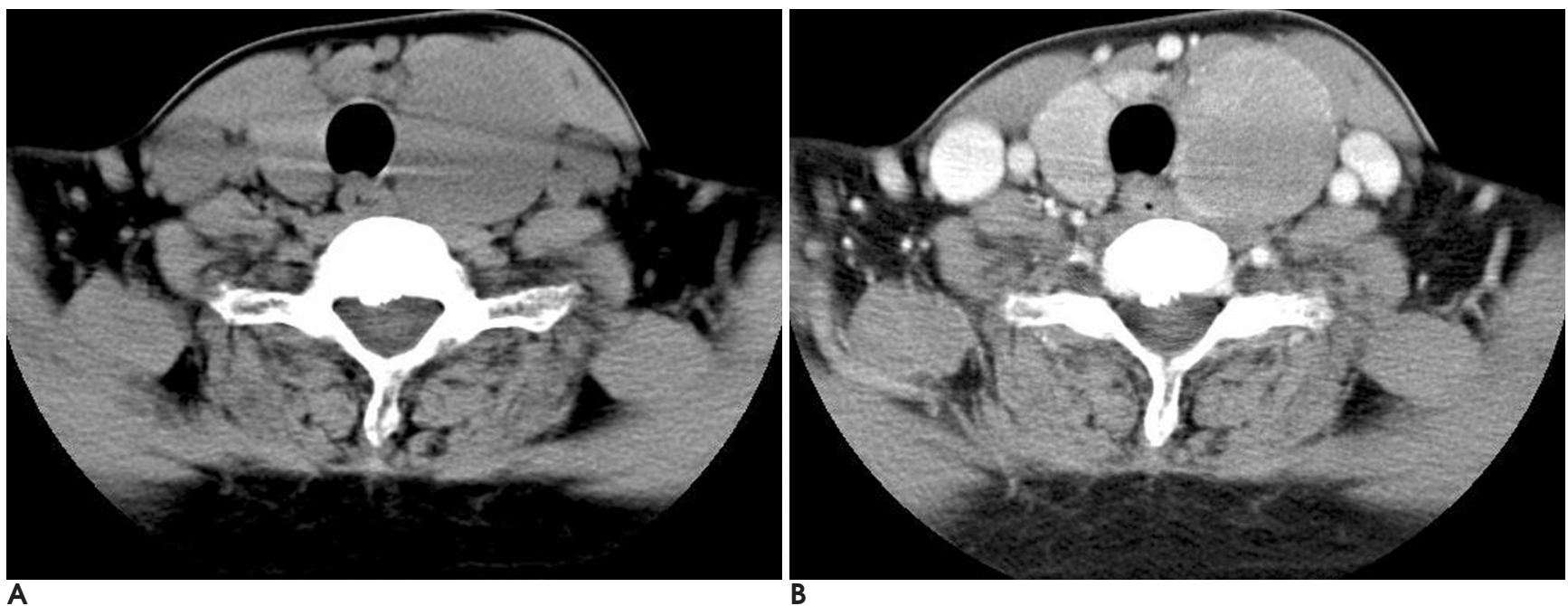

Fig. 3. Nonenhanced CT (NECT) (A) demonstrates diffuse asymmetric enlargement of the thyroid gland. The density of both thyroid lobes is homogeneously lower than that of the muscles of the neck. On contrast enhanced CT (CECT) (B), the left thyroid lobe is nearly replaced by a large homogeneously enhancing solid mass. The density of the mass is slightly lower than that of the surrounding thyroid tissue. The thyroid tissue that's not involved by a mass is hypodense on NECT (A), suggesting coexisting Hashimoto's thyroiditis. 
The overall 5-year survival for this aggressive tumor group is less than $50 \%$. Treatment options are surgical resection for the localized, low-grade MALT lymphomas or systemic chemotherapy for the aggressive, diffuse large B-cell lymphomas. This has highlighted the role of the diagnostic imaging modalities and also the less invasive diagnostic tools such as FNAC and core-needle biopsy so as to avoid unnecessary surgery.

Hashimoto's thyroiditis is an autoimmune disease that predominantly affects elderly women and it usually manifests as a diffuse goiter. Primary thyroid lymphoma has a strong association with Hashimoto's thyroiditis. Hashimoto's thyroiditis is associated in $80-83 \%$ of the thyroid lymphoma cases (5). Lerma et al. (6) compared the cytologic features of histologically proven lymphocytic (Hashimo's) thyroiditis and primary thyroid lymphoma. According to their study, a heterogeneous population of small and large lymphocytes was the most frequently seen pattern in both diseases. The presence of a

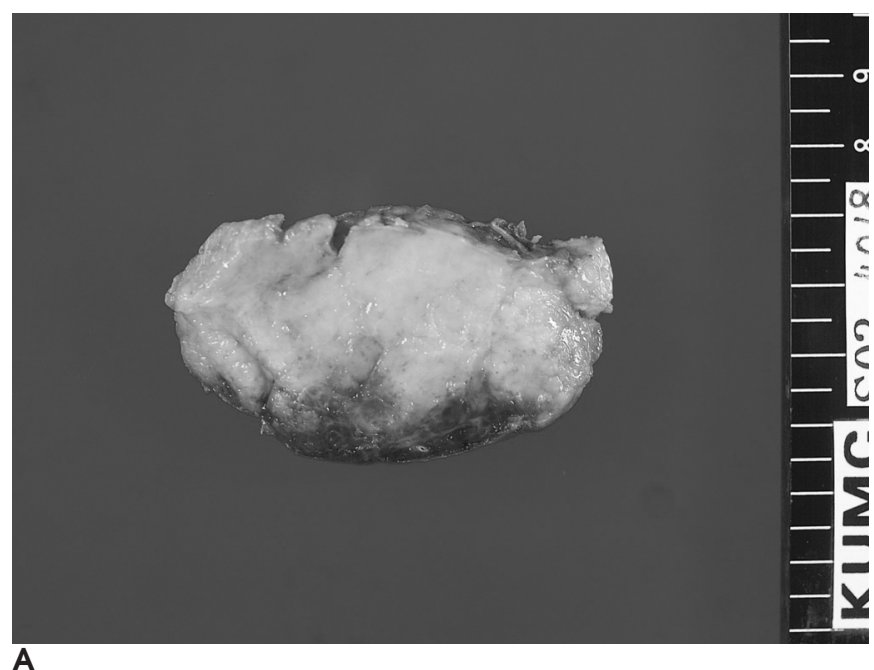

A

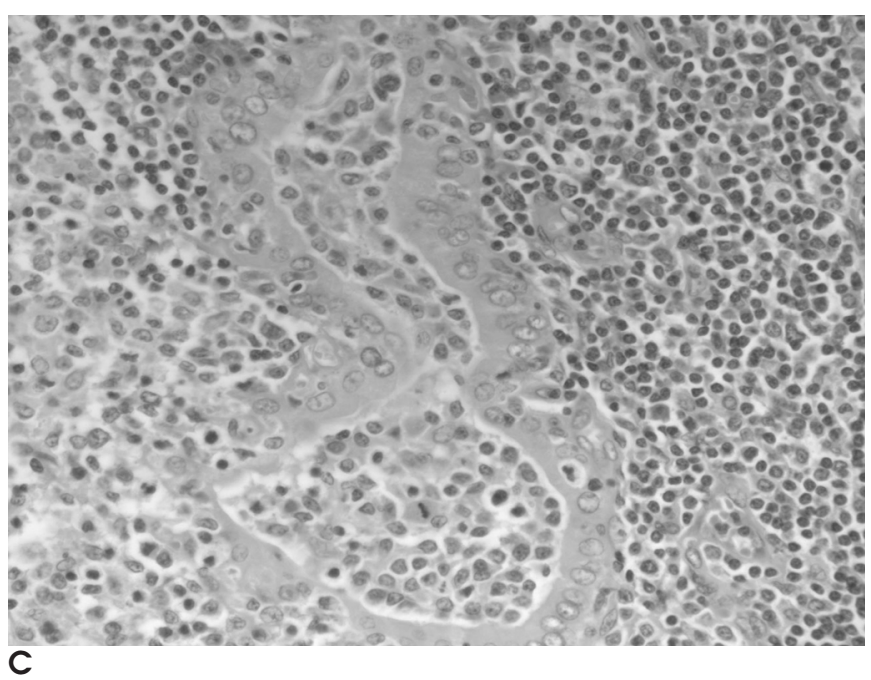

monotonous population of large lymphocytes or, more rarely, of small cells indicates a probable thyroid lymphoma. The finding of plasma cells favors Hashimoto's thyroiditis. The use of other techniques is mandatory for the differentiation of cases that have inconclusive diagnoses.

Subacute thyroiditis accounts for $0.16 \%-0.36 \%$ of all thyroid diseases and this mostly results from viral infections (7). This disorder is most common between the second and fifth decades of life; the female to male ratio ranges from 3:1 to 6:1 (7). The patients with this disorder present with neck pain, thyroid tenderness and the systemic symptoms of inflammatory disease with or without thyrotoxicosis. The most important laboratory data indicating subacute thyroiditis are an increased erythrocyte sedimentation rate, increased serum thyroxine levels and a low uptake of radioactive iodine (8).

Regarding the US findings, anaplastic carcinoma, hemorrhage into a thyroid adenoma, subacute thyroiditis

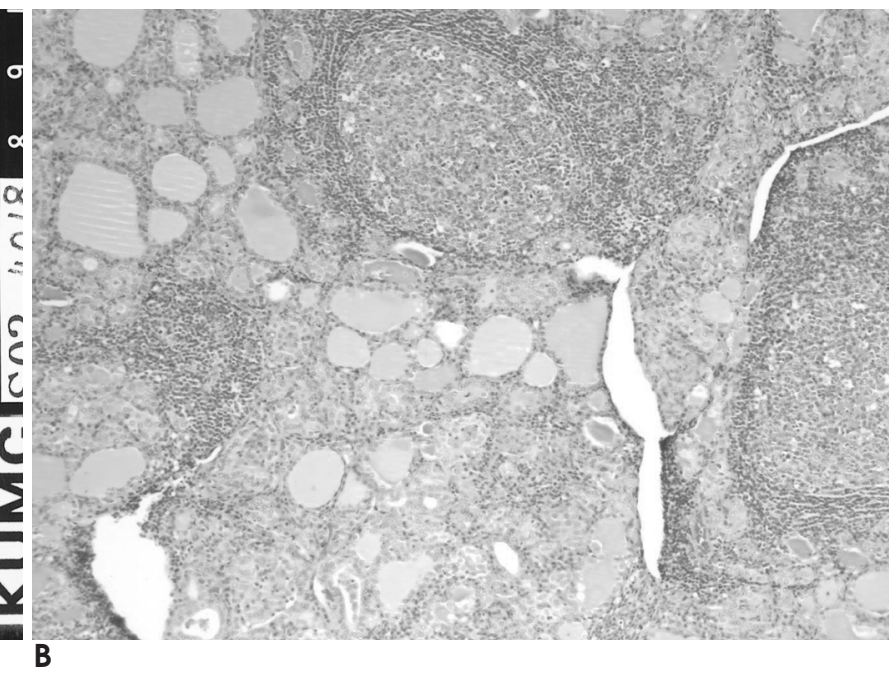

Fig. 4. Grossly (A), the left thyroid lobe measures 7.0× 3.5× 3.0 $\mathrm{cm}$ and it shows a pale-tan to brown, diffusely nodular appearance without a mass lesion. The histologic findings (B) show lymphoid follicle formation surrounding the atrophied follicles, and this is a typical feature of Hashimoto's thyroiditis $(\mathrm{H} \& \mathrm{E}, \times$ 100). The high-power view (C) shows atrophied thyroid follicles infiltrated by monocytoid cells, forming a "lymphoepithelial lesion" $(\mathrm{H} \& \mathrm{E}, \times 400)$. 


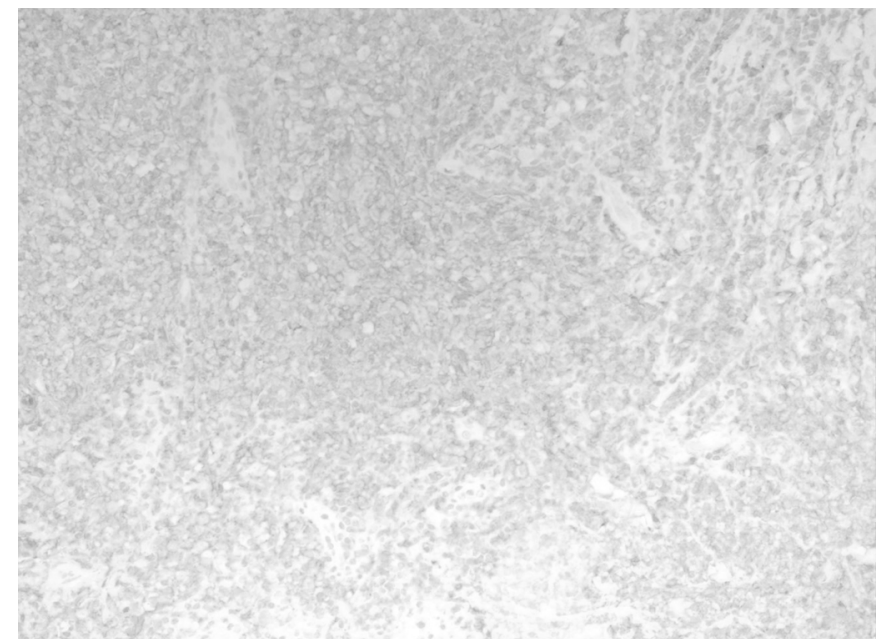

A

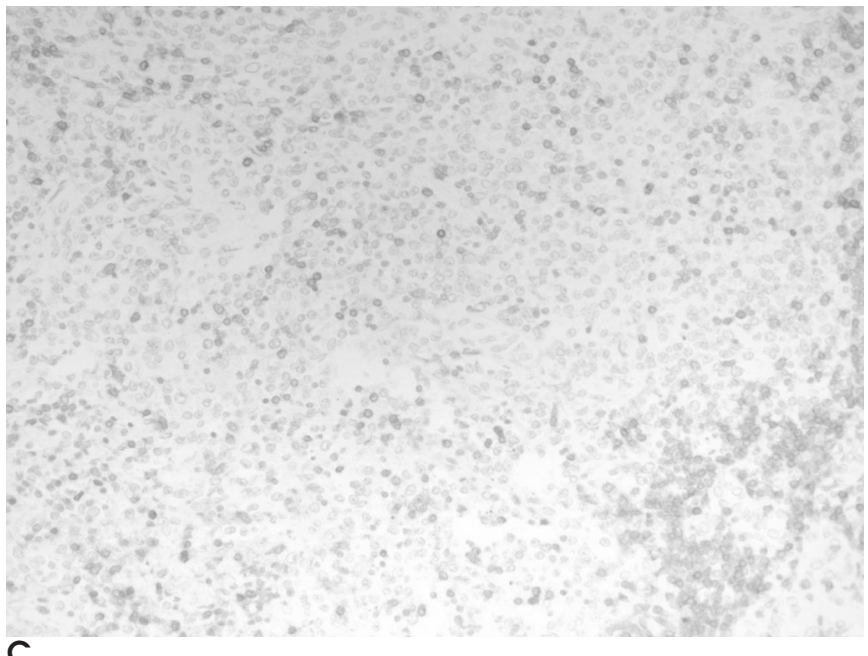

Fig. 5. Immunostaining for CD20 (A) and CD22 (B) shows cytoplasmic staining of the atypical lymphoid cells. There was negative immunostaining for CD5 (C) and CD10 (D). The results of the immunostaining are compatible with mucosa-associated lymphoid tissue (MALT) lymphoma.

and primary thyroid lymphoma may all appear as hypoechoic or markedly hypoechoic on US (8). Anaplastic carcinoma usually shows a single bulky mass that is often accompanied with calcifications, necrosis and invasion to the surrounding structures, including the regional lymph nodes. Hemorrhagic thyroid adenoma will have a cystic component on US with well-defined margins and frequently a halo. Primary thyroid lymphoma confined the thyroid gland will appear as a homogeneous markedly hypoechoic mass or masses that are rarely associated with necrosis, which is very similar to our case. Takashima et al (9) mentioned that 30 (97\%) of 31 primary thyroid lymphomas showed well-defined margins. On the contrary, subacute thyroiditis is reported to usually show an ill-defined margin. The margin characteristics seen on US may be a clue for discriminat-
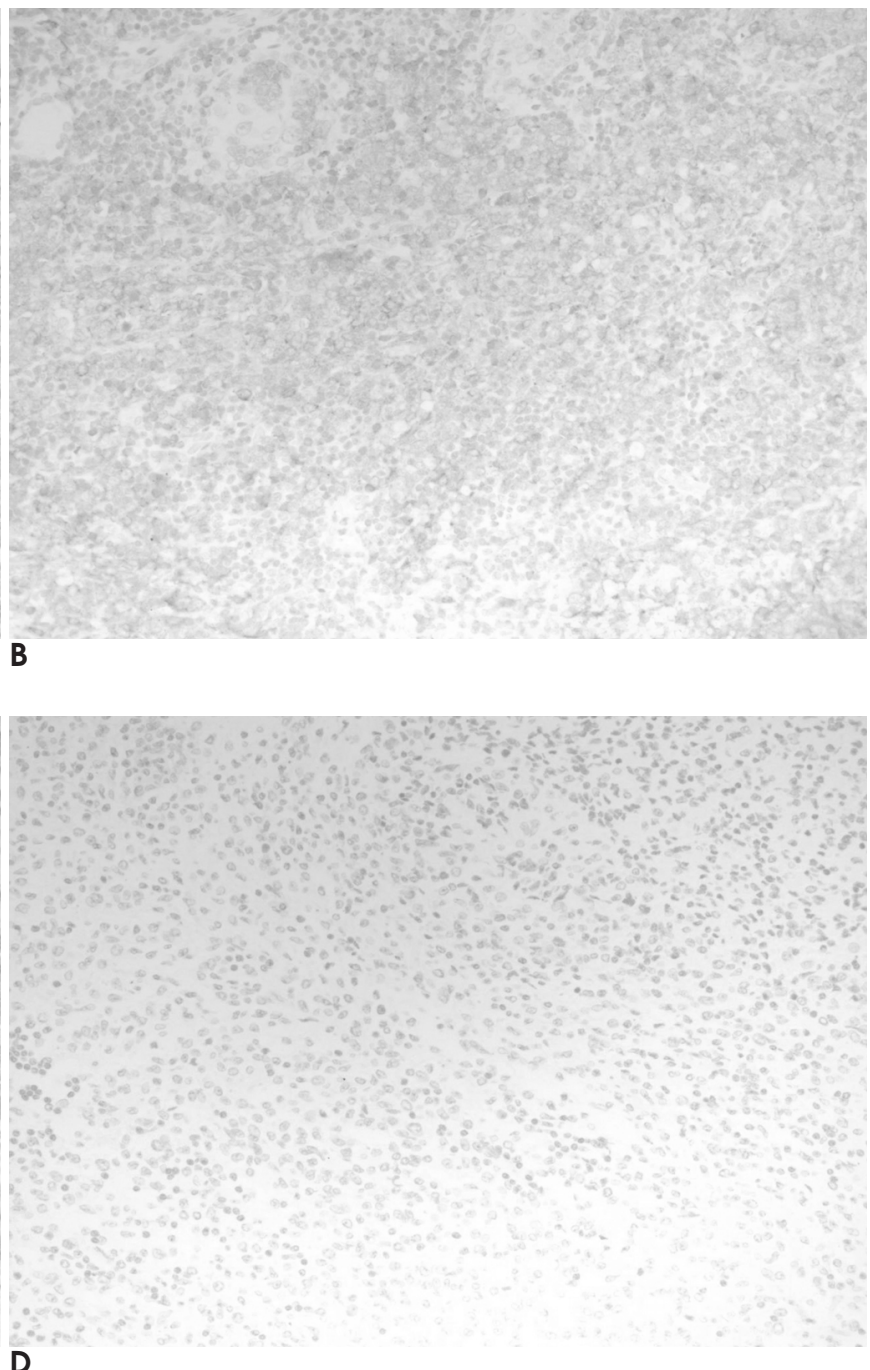

lasmic staining of the atypical lymphoid cells. There was negative
mmunostaining are compatible with mucosa-associated lymphoid 
vide an adequate sample or the cytologic findings are indeterminate in $10 \%-20 \%$ of cases, and in some cases, it is difficult to distinguish primary thyroid lymphoma from Hashimoto's thyroiditis or small cell undifferentiated carcinoma (anaplastic carcinoma) (5). Core-needle biopsy produces a histologic sample that retains its cytologic appearance and its tissue architecture, and this procedure may provide a more precise histologic diagnosis (10). The development of a fine-gauge disposable single-action biopsy needle has greatly facilitated imageguided biopsy of head and neck lesions. By using singleaction core biopsy needles, the needle trocar does not advance when the spring-loaded cutting sheath is activated, which helps to prevent damage to the adjacent structures. The rationale of the open surgical biopsy is that an incisional thyroid biopsy confirms the histological diagnosis with about a $90 \%$ accuracy rate. Moreover, this procedure supplies a sufficient tissue sample for classification.

The diagnosis of primary MALT lymphoma of the thyroid gland in the current case was delayed until 10 months after the initial visit when open surgical biopsy confirmed the primary MALT lymphoma of the thyroid gland.

We suggest that primary MALT lymphoma of the thyroid gland that occurs in coexisting Hashimoto's thyroiditis may mimic lymphocytic or subacute thyroiditis both clinically and cytomorphologically; in such circumstances, the characteristic imaging findings of a well circumscribed markedly hypoechoic mass on US and a homogeneously enhancing solid mass on CT should be carefully searched for to make an accurate diagnosis of primary MALT lymphoma of the thyroid gland. Taking into account our experience with FNAC, we prefer coreneedle biopsy or open surgical biopsy in the cases where the clinical impression and imaging findings are highly suggestive of primary lymphoma of the thyroid gland.

\section{References}

1. Esselstyn CB Jr, Crile G Jr. Evaluation of various types of needle biopsies of the thyroid. World J Surg 1984;8:452-457

2. Mambo NC, Irwin SM. Anaplastic small cell neoplasms of the thyroid: an immunoperoxidase study. Human Pathol 1984;15:55-60

3. Gruckman JL. A practical approach to thyroid tumors. In Shockley WW, Pillsbury III HC. The Neck: diagnosis and surgery. St Louis: Mosby, 1994:223-240

4. Pedersen RK, Pedersen NT. Primary non-Hodgkin's lymphoma of the thyroid gland: a population based study. Histopathology 1996; 28:25-32

5. Aozasa K, Inoue A, Tajima K, Miyauchi A, Matsuzuka F, Kuma K. Malignant lymphomas of the thyroid gland: analysis of 79 patients with emphasis on histological prognostic factors. Cancer 1986;58: 100-104

6. Lerma E, Arguelles R, Rigla M, Otal C, Cubero JM, Bague S, et al. Comparative findings of lymphocytic thyroiditis and thyroid lymphoma. Acta Cytol 2003;47:575-580

7. Nikolai TF. Silent thyroiditis and subacute thyroiditis. In Braverman LE, Utiger RD. Werner and ingbar's the thyroid. 6th ed. Philadelphia, Lippincott, 1991:710-727

8. Takashima S, Morimoto S, Ikezoe J, Arisawa J, Hamada S, Ikeda $\mathrm{H}$, et al. Primary thyroid lymphoma: comparison of CT and US assessment. Radiology 1989;171:439-443

9. Takashima S, Matsuzuka F, Nagareda T, Tomiyama N, Kozuka T. Thyroid nodules associated with Hashimoto thyroiditis: assessment with US. Radiology 1992;185:125-130

10. Lo Gerfo P, Colacchio T, Caushaj F, Weber C, Feind C. Comparison of fine-needle and core-needle biopsies in evaluating thyroid nodules. Surgery 1982;92:835-838

\title{
하시모토 갑상선염을 가진 환자의 갑상선에서 병발한 일차성 점막관련림프조직 림프종: 1 예 보고 ${ }^{1}$
}

${ }^{1}$ 계명대학교 의과대학 동산의료원 영상의학과학교실

${ }^{2}$ 계명대학교 의과대학 동산의료원 병리학교실

\author{
이상권- 권선영 ${ }^{2}$ 김영환 최진수 손철호. 이희정. 우성구. 서수지
}

저자들은 하시모토 갑상선염이 있는 57세 여자 환자의 갑상선에서 생긴 1차성 점막관련 림프조직 림프종 (primary mucosa associated lymphoid tissue lymphoma) 1예를 특징적인 영상 소견, 병리조직학적 소견 및 면역조직화학 적 소견과 함께 보고하고자 한다. 